\title{
Pemanfaatan Dana Corporate Social Responsibility Bank Syariah Mandiri Cabang Kendari
}

\author{
Muhamad Turmudi \\ Fakultas Ekonomi dan Bisnis Islam Institut Agama Islam Negeri Kendari, Indonesia \\ mturmudi76@gmail.com
}

\begin{abstract}
This study examines a Corporate Social Responsibility Program of Syariah Banking so as to provide an understanding of the existence, implementation and source of funds of social programs developed through the utilization of corporate social responsibility funds in Islamic banking institutions especially at Bank Syariah Mandiri Branch of Kendari. This study is limited to the management and utilization of corporate social responsibility funds in 2017. The existence of corporate social responsibility program undertaken by Bank Syariah Mandiri Branch of Kendari in 2017 was under the theme of BSM Mengalirkan Berkah. The implementation of this program conducted until October 2017 were (1) mosque development activities with the Rp. 200 million as the funding with such details as $2 \%$ for Program Preparation, for direct assistance mosque taking up to $60 \%$, for other assistance up to $30 \%$, for Assistance program as much as $6 \%$, and for monitoring and evaluation up to $2 \%$. (2) Donations for mosques that are used as the place of doing a lot of dawn worship programs (3) Provision of clean water (4) Scholarship program for students. Furtherore, the funding of Corporate social responsibility programs which is channeled to the community comes from zakah funds, corporate profits and the fund of virtue (Qardh al-hasan).
\end{abstract}

\section{Keywords: corporate social responsibility; Bank Syari'ah Mandiri}

\begin{abstract}
Abstrak
Penelitian ini mengkaji tentang Program corporate social responsibility di Perbankan Syariah sehingga memberi pemahaman mengenai eksistensi, implementasi serta sumber dana program sosial yang dikembangkan melalui pemanfaatan dana corporate sosial responsibility dilembaga perbankan syariah, khususnya di Bank Syariah Mandiri Cabang Kendari ditahun 2017. Eksistensi Program corporate social responsibility yang dilakukan Bank Syariah Mandiri Cabang Kendari pada tahun 2017 memiliki tema BSM Mengalirkan Berkah. Sampai bulan Oktober 2017, program diimplementasikan pada (1) kegiatan pengembangan masjid dengan nominal penyaluran sampai dengan Rp. 200 juta dengan perincian persiapan program $2 \%$, bantuan langsung masjid $60 \%$, bantuan lain $30 \%$, Pendampingan program $6 \%$, monitoring dan evaluasi $2 \%$, sumbangan untuk masjid yang dijadikan tempat pada program subuh berjamaah, pengadaan air bersih, dan program pemberian beasiswa bagi mahasiswa. Dana Program corporate social responsibility yang disalurkan kepada masyarakat tersebut berasal dari dana zakat, laba perusahaan serta dana kebajikan (Qardh al-hasan).
\end{abstract}

\section{Kata Kunci: corporate social responsibility; BSM mengalirkan berkah}

\section{A. Pendahuluan}

Tanggung jawab sosial perusahaan yang dikenal dengan istilah corporate social responsibility (CSR) merupakan tanggung jawab yang melekat pada setiap perusahaan penanaman modal untuk tetap menciptakan hubungan yang serasi, seimbang, dan sesuai dengan lingkungan, nilai, norma, dan budaya masyarakat setempat, ${ }^{1}$ sehingga Setiap perusahaan diharuskan melaksanaan program corporate social responsibility sebagai bentuk tanggung jawab sosial dan lingkungan yang harus dijadikan sebagai komitmen perseroan

\footnotetext{
${ }^{1}$ Penjelasan Pasal 15 Huruf b, Undang Undang Republik Indonesia Nomor 25 Tahun 2007 Tentang Penanaman Modal.
} 
dengan ikut serta dalam pembangunan ekonomi yang berkelanjutan sehingga mampu meningkatkan kualitas kehidupan serta lingkungan yang bermanfaat untuk perusahaan tersebut, komunitas setempat ataupun masyarakat. ${ }^{2}$

Corporate social responsibility (CSR) merupakan komitmen dunia usaha untuk terus menerus bertindak secara etis, beroperasi secara legal dan berkontribusi untuk peningkatan ekonomi, peningkatan kualitas hidup dari karyawan dan keluarganya sekaligus juga peningkatan kualitas komunitas lokal dan masyarakat secara lebih luas. ${ }^{3}$

Program corporate social responsibility di Perbankan Syariah sejalan dengan prinsip syariah sebagai dasar perbankan syariah dimana transaksi bisnis dalam perspektif syariah tidak dapat dipisahkan dari tujuan moral masyarakat sehingga mampu memberikan kesejahteraan bagi masyarakat luas.

Pelaksanaan tanggung jawab sosial perusahaan merupakan bagian dari investasi sosial perusahaan yangdapat memberikan kontribusi dalam upaya pemberdayaan masyarakat untuk memanfaatkan sumberdaya dan peluang ekonomi secara bertanggung jawab dan berkelanjutan demi terpenuhinya kebutuhan dasar masyarakat. ${ }^{4}$ Program-program tanggung jawab sosial perusahaan yang langsung berhubungan dan memberikan dampak langsung kepada masyarakat dapat meningkatkan penilaian yang baik bagi perusahaan serta mampu menjadi penunjang strategi bisnis.

Program corporate social responsibility perbankan syariah harus benar-benar menyentuh kebutuhan asasi masyarkat yang dapat menciptakan kesejahteraan ekonomi yang merata ${ }^{5}$ sehingga tanggung jawab sosial yang dilakukan perbankan syariah dapat menjadikan perbankan syariah menjadi sebuah lembaga yang mampu mensejahterakan masyarakat.

Tulisan yang membahas mengenai program corporate social responsibility sangat beragam, diantaranya adalah Pengaruh Corporate social responsibility terhadap Profitabilitas Perusahaan yang diukur dengan return on asset (ROA), Return on Equity (ROE) serta Net Profit Margin (NPM) ${ }^{6}$ Islamic Corporate Social Responsibility (ICSR); Kajian Teoritis yang menyatakan bahwa ICSR dibagi menjadi tiga konsep, yaitu konsep kerohanian, rahmatan lil'alamin serta ukhuwah islamiyah. ICSR mewajibkan untuk mengedepankan kepentingan dharuriyyah tercapai lebih dahulu, dilanjutkan hajiyyah dan tahsiniyah, ${ }^{7}$ serta Pengaruh Corporate social responsibility Terhadap Nilai Perusahaan. Dengan profitabilitas sebagai variabel moderating, penelitian tersebut menguji dan menganalisis pengaruh tanggungjawab sosial perusahaan terhadap nilai perusahaan. ${ }^{8}$

\section{B. Urgensi Corporate Social Responsibility}

\footnotetext{
${ }^{2}$ Undang-Undang Republik Indonesia Nomor 40 Tahun 2007 Tentang Perseroan Terbatas, Bab I: Ketentuan Umum Pasal 1 Ayat 3

${ }^{3}$ Yusuf Wibisono, Membedah Konsep dan Aplikasi CSR, cet. II, (Gersik: Fascho Publishing, 2007), h. 7.

${ }^{4}$ Riza Primahendra, Corporate Social Responsibility Sebagai Investasi Sosial (Jakarta: Brief Note, Amerta Sosial Consulting \& Resourching, 2010), hal. 3

${ }^{5}$ Yusuf Yasir, "Aplikasi Corporate social responsibility pada Bank Syariah: Suatu Pendekatan Maslahah Dan Maqasid Syariah”, Jurnal EKSIBISI, Vol 4, No 2, juni 2010, h. 100.

${ }^{6}$ Anggara Satria Putra, "Pengaruh Corporate social responsibility Terhadap Profitabilitas Perusahaan (Studi Empiris pada Perusahaan Sektor Industri Barang Konsumsi yang Terdaftar di Bursa Efek Indonesia Tahun 2010-2013)", Jurnal Nominal, Volume IV Nomor 2, 2015, http://download.portalgaruda.org/article.php?article diakses tanggal 15 Desember 2016.

${ }^{7}$ Wahyuddin, "Islamic Corporate social responsibility (ICSR); Kajian Teoritis", http://jurnal2.serambimekkah.ac.id/wp-content/uploads/2016/05/ dikses tanggal 15 Desember 2016

${ }^{8}$ Arik Novia Handriyani, "Pengaruh Corporate social responsibility Terhadap Nilai Perusahaan Dengan Profitabilitas Sebagai Variabel Moderating", https://ejournal.stiesia.ac.id/jira/article/viewFile/124/123 diakses tanggal 15 Desember 2016.
} 
Penerapan CSR berkembang akibat respon dunia usaha yang melihat aspek lingkungan dan sosial merupakan peluang untuk meningkatkan daya saing serta menjadi bagian dari pengelolaan risiko menuju sustainability perusahaan. Substansi CSR merupakan kemampuan perusahaan beradaptasi dengan lingkungan, komunitas serta stakeholder dari perusahaan tersebut. Sebagai bentuk perwujudan CSR yang dilakukan oleh perusahaan swasta, kementrian BUMN mengeluarkan program kemitraan dan bina lingkungan (PKBL) ${ }^{9}$ dengan harapan menghasilkan tiga pilar, yaitu (1) pembangunan dengan tujuan mengurangi pengangguran (2) mengurangi jumlah penduduk miskin (3) meningkatkan pertumbuhan ekonomi.

CSR yang dilakukan perusahaan berorientasi pada dua hal, yaitu (1) orientasi internal yakni program CSR yang berupa tindakan atas program yang diberikan kepada komunitas perusahaan; (2) orientasi eksternal yakni program CSR berupa nilai perusahaan yang digunakan untuk mewujudkan tindakan-tindakan yang sesuai dengan keadaan sosial masyarakat dan komunitas sekitarnya. Sebelum merealisasikan CSR perusahaan dapat merencanaan pelaksanaan melalui tiga langkah yaitu:

a. Awareness building, merupakan langkah awal untuk membangun kesadaran mengenai arti penting CSR dan komitmen manajemen. Upaya ini dapat dilakukan antara lain melalui seminar, lokakarya dan lain-lain.

b. CSR assessement, merupakan upaya untuk memetakan kondisi perusahaan dan mengidentifikasi aspek-aspek yang perlu mendapatkan prioritas perhatian dan langkahlangkah yang tepat untuk membangun struktur perusahaan yang kondusif bagi penerapan CSR yangefektif.

c. CSR manual building yakni penyusunan manual CSR dibuat sebagai acuan, pedoman dan panduan dalam pengelolaan kegiatan-kegiatan sosial kemasyarakatan yang dilakukan oleh perusahaan. Penyusunan manual ini dapat dilakukan dengan meminta bantuan tenaga ahli independen dari luar perusahaan. ${ }^{10}$

CSR juga merupakan komitmen bisnis perusahaan untuk berkontribusi pada pembangunan ekonomi berkelanjutan yang bekerja sama dengan para pekerja, keluarga mereka serta masyarakat sekitar perusahaan (komunitas lokal) ${ }^{11}$ sehingga program CSR dapat berkontribusi terhadap perkembangan ekonomi yang berkelanjutan dengan menitikberatkan pada keseimbangan aspek ekonomi, sosial dan lingkungan. ${ }^{12}$

Pelaksanaan CSR oleh perusahaan pada dasarnya memiliki bebrapa alasan yang sejalan dengan operasional perusahaan, yakni (1) perusahaan merupakan bagian dari masyarakat, oleh karenanya sangat wajar jika perusahaan memperhatikan kepentingan masyarakat; (2) pengusaha dan masyarakat harus memiliki hubungan yang bersifat saling ketergantungan sehingga perusahaan akan mendapatkan dukungan dari masyarakat; (3) CSR merupakan tanggung jawab sosial perusahaan yang dapat meredam atau menghindari konflik.

Dari alasan tersebut dapat uraikan beberapa keuntungan yang dapat diperoleh perusahaan jika melaksanakan program CSR yaitu (1) mempertahankan dan mendongkrak reputasi dan citra perusahaan; (2) berhak mendapatkan sosial license to operate masyarakat sekitar sebagai komunitas utama perusahaan; (3) mereduksi risiko bisnis perusahaan sehingga pelaksanaan CSR merupakan langkah preventif pencegahan memburuknya hubungan dengan stakeholder; (4) melebarkan akses daya; pelaksanaan CSR yang baik merupakan keunggulan bagi perusahaan untuk mendapatkan sumberdaya yang dibutuhkan; (5) membuka akses menuju market; (6) mereduksi biaya; (7) memperbaiki hubungan dengan stakeholder; (8)

\footnotetext{
${ }^{9}$ Kepmen BUMN Nomor: Kep-236/MBU/2003 tentang Program Kemitraan Bina Lingkungan (PKBL)

${ }^{10}$ Ibid. h. 127.

${ }^{11}$ Ibid, h. 26.

${ }^{12}$ Hendrik B. Untung, Corporate social responsibility, (Jakarta: Sinar Grafika, 2008), h. 1.
} 
memperbaiki hubungan dengan regulator; (9) meningkatkan semangat dan produktifitas karyawan; serta (10) peluang mendapatkan penghargaan. ${ }^{13}$

Tingkat keberhasilan program CSR dapat terlihat dari aspek internal dan eksternal. Indikator aspek internal dapat terlihat dari sedikitnya konflik ataupun potensi konflik antara perusahaan dengan masyarakat yang dapat membentuk hubungan yang harmonis dan kondusif sehingga semua asset perusahaan dapat terpelihara dan seluruh kegiatan perusahaan dapat berjalan dengan lancar. Indikator aspek eksternal dapat terlihat dari faktor ekonomi dengan adanya peningkatan pertambahan kualitas sarana dan prasarana umum, peningkatan kemandirian masyarakat secara ekonomis serta peningkatan kualitas hubungan sosial antara perusahaan dan masyarakat. ${ }^{14}$

Perusahaan bukanlah entitas yang hanya beroprasi untuk kepentingannya sendiri, namun juga harus mampu memberikan manfaat bagi stakeholder baik konsumen, supplier, investor termasuk masyarakat yang berada disekitar lingkungan perusahaan. Dalam cakupan implementasi program CSR, stakeholders digolongkan ke dalam dua bagian yaitu stakeholders internal yakni karyawan, keluarga karyawan dan shareholders dan stakeholders eksternal yaitu costomer, lingkungan hidup dan supplier. Bentuk Stakeholders tersebut dapat dilihat dalam bagan berikut: ${ }^{15}$

Bagan 1; Stakeholder Internal

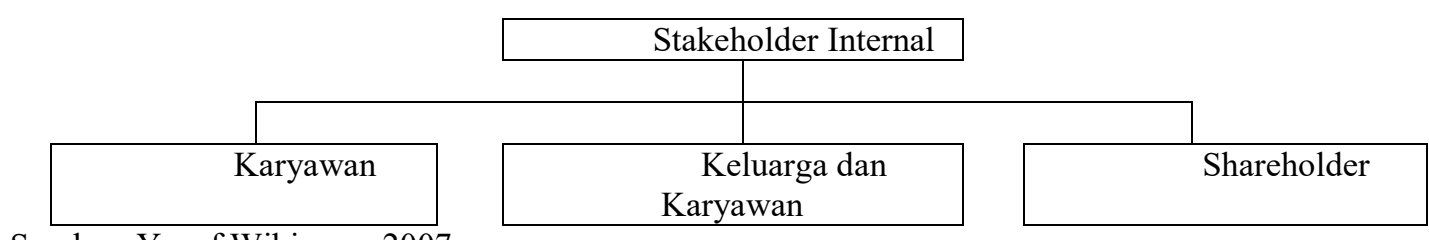

Sumber: Yusuf Wibisono, 2007

Bagan 2; Stakeholder Eksternal

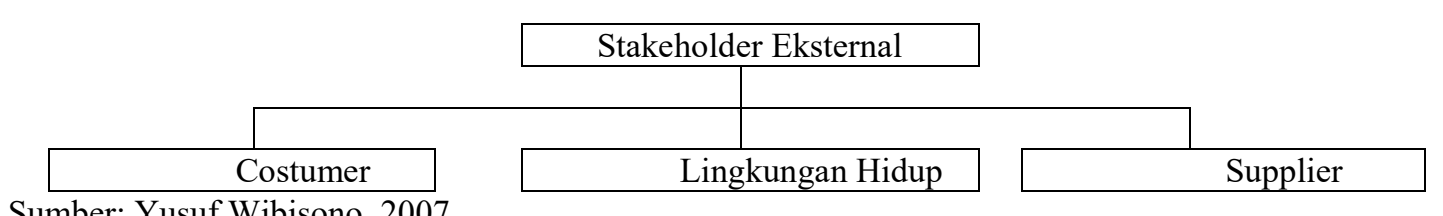

Sumber: Yusuf Wibisono, 2007

Konsep pengembangan CSR bukan hanya dihadapkan pada tanggung jawab yang berpijak pada aspek ekonomi yang direfleksikan dalam kondisi keuangan semata, tetapi harus memperhatikan aspek sosial dan lingkungannya sehingga keuntungan ekonomis tidak dapat dipisahkan dalam kerangkan pelaksanaan program tersebut, ${ }^{16}$ karenanya terdapat tiga domain utama bagi perusahan ketika melaksanakan tanggung jawab sosialnya, yaitu: ${ }^{17}$

a. Pelaku organisasi, meliputi hubungan perusahaan dengan pekerja, hubungan pekerja dengan perusahaan serta hubungan perusahaan dengan pelaku usaha lain dan konsumen.

b. Melestarikan lingkungan alam, manusia sebagai mahluk yang paling sempurna diciptakan Allah swt. sekaligus diberi tugas menjadi khalifah di bumi diperintahkan untuk menjaga kelestarian alam.

\footnotetext{
${ }^{13}$ Yusuf Wibisono, Membedah Konsep.

${ }^{14}$ Yusuf Wibisono, Membedah Konsep, h. 147.

${ }^{15}$ Yusuf Wibisono, Membedah Konsep. h. 33.

${ }^{16}$ Ibid. h. 32.

${ }^{17}$ Sayyid Qutb, Tafsir Fi Zhilalil Qur'an di Bawah Naungan Al-Qur'an, Jilid 4, (Jakarta: Gema Insani Press, 2001), h. 253-254.
} 
c. Kesejahteraan sosial masyarakat yang pada intinya mencakup dua hal pokok yakni, kesejahteraan yang bersifat jasmani dan kesejahteraan yang bersifat rohani. Kesejahteraan tersebut harus dapat terwujud bagi setiap pekerja sehingga akan tercipta kesejahteraan individu, keluarga, masyarakat bahkan Negara

CSR yang dapat dikembangkan merupakan gambaran kepedulian perusahaan didasari atas tiga prinsip yang dikenal dengan istilah Triple Bottom Line sebagaimana tergambar pada bagan berikut: ${ }^{18}$

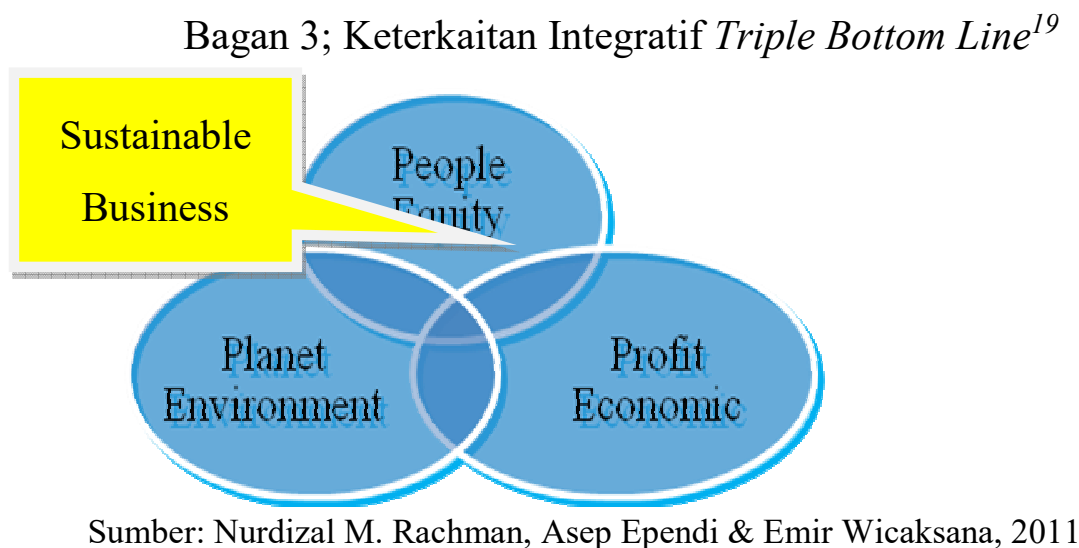

1. Profit economic merupakan perolehan keuntungan yang menjadi tujuan kegiatan usaha. Setiap perusahaan berorientasi mendapat keuntungan dari setiap aktifitas bisnisnya sehingga mampu terus menjalankan bahkan mengembangkan usahanya. Untuk memperoleh profit, perusahaan harus mampu meningkatkan produktivitas serta melakukan efisiensi biaya sehingga memiliki keunggulan kompetitif yang mampu memberikan nilai tambah maksimal. ${ }^{20}$

2. People equity merupakan teori yang membicarakan mengenai manusia dan penciptaan nilai yang berdampak pada kualitas hidup individu, organisasi bahkan peradaban manusia. People equity yang rendah terlihat dari konflik produktivitas rendah, kerjasama tim menjadi rendah atau karyawan yang merasa tidak nyaman sehingga menginginkan keluar dari perusahaan. Sebaliknya perusahaan dengan penerapan people equity baik berdampak pada karyawan yang merasa bangga terhadap organisasi beserta misi dan perannya. Mereka menunjukkan loyalitas dan identifikasi tinggi terhadap organisasi. Mereka bersedia mengadvokasi orang untuk datang bergabung atau melakukan investasi di perusahaan mereka. ${ }^{21}$

3. Planet environment, semua yang terkait dengan kehidupan manusia, semua kegiatan manusia sebagai mahluk hidup selalu berhubugan dengan lingkungan sekitar, misalkan air, udara serta peralatan yang digunakan dalam beraktivitas semuanya berasal dari lingkungan/alam. ${ }^{22}$ Lingkungan juga merupakan tempat dimana perusahaan berdiri dan berproduksi sehingga menghasilkan produk bernilai ekonomis yang dapat memberikan keuntungan bagi perusahaan. Hubungan manusia dengan lingkungan digambarkan bahwa Allah swt. menciptakan alam semesta untuk keperluan manusia sehingga dapat saling

\footnotetext{
${ }^{18}$ Nurdizal M. Rachman, Asep Ependi \& Emir Wicaksana, Panduan Lengkap Perencanaan CSR, (Jakarta: Penebar Swadaya, 2011), hal. 12.

${ }^{19}$ Ibid, h. 12.

${ }^{20} \mathrm{Ibid}, \mathrm{h} .163$

${ }^{21}$ http://www.jtanzilco.com/blog/detail/360/slug/people-equity-pendekatan-baru-talent-management-untukmendongkrak-kinerja-organisasi, diakses tanggal 30 Agustus 2017

${ }^{22}$ Yusuf Wibisono, Membedah Konsep, h. 87.
} 
bersinergi sebagai sunnatullah yang terkandung dalam tiga elemen yakni manusia, agama (yang terkandung dalam prinsip-prinsip syari'ah) serta lingkungan (alam) dengan segala isinya sebagaimana terlihat pada bagan berikut: ${ }^{23}$

Bagan 4; Hubungan Manusia dan Lingkungan

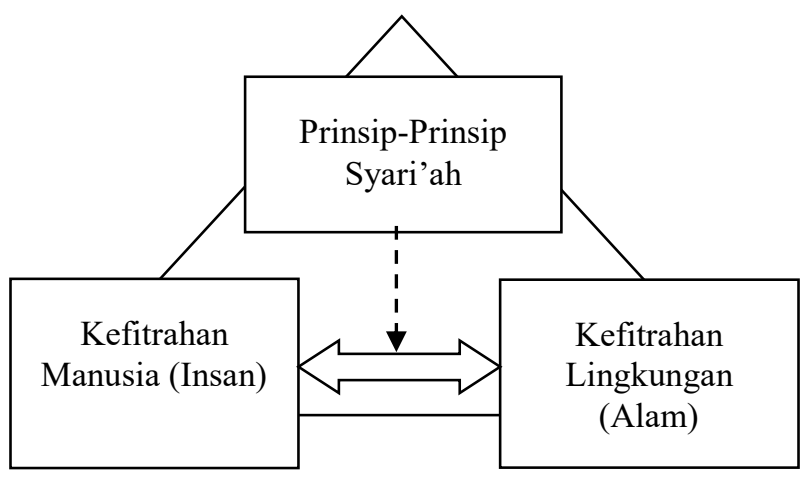

Sumber: Ali Sakti

Implementasi tanggung jawab sosial dalam nilai-nilai ekonomi Islam harus memenuhi beberapa unsur, yaitu: ${ }^{24}$

a. Al-'Adl; Islam mengajarkan keseimbangan sosial dan keseimbangan alam harus tetap terjaga serta mengharuskan setiap orang untuk berbuat adil terhadap hak orang lain, hak lingkungan sosial serta hak alam semesta. Dalam oprasional perusahaan/bisnis, Islam melarang adanya segala bentuk penipuan, gharar (spekulasi), najsh (iklan palsu) dan ihtiqar (penimbunan) yang akan merugikan pihak lain.

b. Al-Ihsan; Bisnis yang dilandasi ihsan merupakan bisnis yang dijalankan dengan proses niat, sikap, perilaku serta transaksi yang baik sehingga mampu memberikan keuntungan lebih kepada stakeholders. Perusahaan tersebut menjalankan bisnis dengan melakukan kebaikan meskipun tanpa ada unsur paksaan/kewajiban untuk melakukan hal tersebut.

c. Al-Manfa'ah; Konsep manfaat yang diemban perusahaan dalam menjalankan tanggung jawab sosial perusahaannya tidak hanya dalam aktivitas ekonomi, melainkan memberikan manfaat yang lebih luas dalam berbagai aspek sosial seperti pendidikan, kesehatan, pemberdayaan masyarakat ataupun pelestarian lingkungan.

d. Al-Amanah; Konsep amanah merupakan niat dan tekad yang harus dijalankan dalam pengelolaan sumber daya manusia ataupun sumber daya alam. Secara makro konsep amanah dapat direalisasikan perusahaan dengan melaksanakan perbaikan sosial dan menjaga keseimbangan lingkungan. Sedangkan secara mikro perusahaan bertanggung jawab dalam menghasilkan produk yang berkualitas dan terhindar dari perbuatan tidak terpuji. $^{25}$

\section{Eksistensi Program Corporate Sosial Responsibility di Bank Syariah Mandiri}

Program tanggung jawab sosial perusahaan Bank Syariah Mandiri yang dikenal dengan program Corporate Social Responsibility Bank Syari'ah mandiri (CSR BSM) merupakan sebuah konsep dimana BSM menyumbangkan dengan sukarela kepada masyarakat untuk lebih baik dengan terus mengupayakan membantu mengurangi dan mengatasi permasalahan

${ }^{23}$ Ali Sakti, Analisis Teoritis Ekonomi Islam, (Jakarta: Paradigma AQSA Publishing, 2007), h. 83.

${ }^{24}$ Ibid, h. 24.

${ }^{25}$ Muhammad dan Lukman Fauroni, Visi Al-Qur'an tentang Etika dan Bisnis (Jakarta: Salemba Diniyah, 2002), h. 99. 
yang terjadi di masyarakat, mengusahakan terjadinya perubahan perilaku masyarakat serta berupaya membantu pencapaian kehidupan masyarakat yang sejahtera. Selain itu, program CSR BSM berupaya menjadikan lingkungan yang lebih bersih. Dengan program CSR BSM diharapkan mampu membentuk hubungan sinergisitas antara perusahaan dengan semua stakeholders yang di dalamnya termasuk nasabah, pegawai, komunitas, pemilik, pemerintah, supplier serta kompetitor bisnis. Aktivitas tanggung jawab sosial perusahaan yang dilakukan Bank Syariah Mandiri bertujuan: ${ }^{26}$

a. Mendukung kesejahteraan masyarakat serta meningkatkan kualitas lingkungan

b. Mendukung implementasi praktik bisnis yang transparan dan bertanggung jawab

c. Membuat perubahan positif di tengah masyarakat, khususnya di lingkungan BSM beropersai

d. Membangun citra positif BSM di masyarakat serta menggalang dukungan masyarakat untuk tujuan bisnis BSM

e. Meningkatkan nilai brand BSM dan membangun reputasi yang baik

f. Meningkatkan kesadaran publik tentang BSM melalui kegiatan sosial.

Realisasi program tanggung jawab sosial perusahaan Bank Syariah Mandiri dilaksanakan bekerja sama dengan Lembaga Amil Zakat (LAZNAS) BSM yang merupakan lembaga penyalur dana kebajikan di Bank Syariah Mandiri serta dana zakat yang terkumpul baik dari karyawan Bank Syariah Mandiri maupun nasabah yang menyalurkan zakatnya melalui Bank Syariah Mandiri. ${ }^{27}$ Dalam kegiatan menyalurkan dana sosialnya Bank Syariah Mandiri menyalurkan pada beberapa kegiatan, yaitu:

a. Program Mitra Umat; merupakan program CSR BSM berupa pemberdayaan masyarakat melalui bantuan modal kerja sebagai bentuk program pemberdayaan sektor ekonomi mikro yang disalurkan kepada pedagang atau pengusaha kecil dan menengah terutama bagi mereka yang berada di sekitar Bank Syariah Mandiri tersebut berada sebagai bentuk dengan menggunakan akad qardhul hasan. Dana tersebut merupakan dana bergulir yang jika usahanya sudah berkembang maka dananya akan digulirkan kepada pedagang atau pengusaha kecil dan menengah lainnya.

b. Program Didik Umat; merupakan program sosial Bank Syariah Mandiri yang fokus pada pengembangan sumberdaya manusia Indonesia melalui program penyaluran bantuan biaya pendididkan berupa beasiswa untuk anak-anak dhuafa sehingga bisa melanjutkan sekolah. Sasaran dari program tersebut adalah pemberdayaan pendidikan mulai tingkat SD, SMP, SMU/K serta Perguruan Tinggi. Tahun 2017 sampai dengan bulan Oktober BSM Cabang Kendari memprogramkan pemberian beasiswa kepada 50 orang Mahasiswa. ${ }^{28}$

c. Program Sosial dan Budaya; yang meliputi (1) Program Simpati Umat, merupakan kegiatan tanggung jawab sosial Bank Syariah Mandiri yang berupa penyaluran bantuan dana zakat, bantuan bagi masyarakat yang tidak memiliki biaya untuk berobat, bantuan bagi masyarakat yang menjadi korban bencana alam, pembangunan Masjid dan fasilitas publik serta santunan dhuafa dan yatim-piatu; (2) Program Perbaikan Kesehatan, merupakan program kepedulian Bank Syariah Mandiri yang langsung bersentuhan dengan masyarakat seperti pelaksanaan donor darah, operasi bibir sumbing untuk anak yatim, serta khitanan massal.

${ }^{26}$ Laporan Kegiatan Corporate Sosial Responsibility (CSR) Bank Syariah Mandiri Tahun 2017.

${ }^{27}$ Dadang Ruhiyat, Branch Manager Bank Syariah Mandiri Cabang Kendari, wawancara di Kendari, 25 Agustus 2017.

${ }^{28}$ Jusri, Pawning Officer Bank Syariah Mandiri Cabang Kendari, wawancara di Kendari, 05 September 2017 


\section{D.Sumber Dana Program Corporate Social Responsibility Bank Syariah Mandiri Cabang Kendari}

Dalam melaksanakan program CSR, Bank Syariah Mandiri Cabang Kendari memerlukan dana yang akan dialokasikan kepada beberapa program sosial. Besaran dana sosial tersebut pada dasarnya sudah ditentukan oleh Bank Syariah Mandiri Pusat berdasarkan kinerja setiap cabang.

Dana program corporate social responsibility tersebut diperoleh dari dana zakat baik yang berasal dari nasabah yang menyalurkan zakatnya melalui rekening Bank Syariah Mandiri maupun dana zakat dari karyawan Bank Syariah Mandiri, laba perusahaan yakni keuntungan yang dihasilkan dari produktifitas dan kinerja positif Bank Syariah Mandiri Cabang Kendari tahun 2016 dengan besaran dana CSR sebesar Rp. 200 juta yang disalurkan untuk keperluan infra sturuktur masjid, serta dana kebajikan (Qardh al-hasan). ${ }^{29}$

Dana kebajikan (qardh al-hasan) bersumber dari (1) denda (ta'zir) yang dibebabankan kepada nasabah pembiayaan karena kelalaian dalam memenuhi kewajiban kepada bank dengan besaran sesuai ketentuan internal Bank Syariah Mandiri Cabang Kendari. Perbankan Syariah tidak mengakui dana yang berasal dari denda tersebut sebagai pendapatan Bank, sehingga dialokasikan sebagai dana kebajikan; (2) penerimaan non halal yakni pendapatan bunga yang diperoleh dari investasi ataupun penempatan dana di bank konvensional yang menerapkan sistem bunga. Untuk memisahkan dana yang diperoleh dari pendapatan non halal, bisa menggunakan konsep tafriq al-halal min al-haram, dimana jika tercampur yang halal dan yang haram pada percampuran 'ainiyah (zat) maka akan menjadi haram secara keseluruhan, akan tetapi pada percampuran uang maka yang menjadi haram adalah berdasarkan perolehannya (kasbiyyah) sehingga jumlah uang yang diperoleh secara haram dapat dihitung, maka sisanya adalah halal. Sehingga apabila harta seseorang bercampur antara yang halal dan yang haram, maka yang haram harus dikeluarkan terlebih dahulu sehingga sisanya merupakan harta yang halal dari orang tersebut. ${ }^{30}$ Dalam penyalurannya, dana yang bersumber pada dana kebajikan dialokasikan untuk program beasiswa. Pada tahun 2017. Bank Syariah Mandiri Cabang Kendari memprogramkan pemberian beasiswa sebesar Rp. 100 juta kepada 50 orang mahasiswa, masing-masing mendapatkan Rp. 2 juta. ${ }^{31}$

\section{E. Implementasi Pemanfaatan Dana Corporate Social Responsibility Bank Syariah Mandiri Cabang Kendari Tahun 2017}

Bank Syariah Mandiri Cabang Kendari selaku lembaga keuangan yang memiliki peran agen of development berusaha untuk mengimplementasikannya melalui program CSR dalam rangka membantu mewujudkan tatanan kehidupan masyarakat menjadi lebih baik. Implementasi penyaluran dana CSR merupakan proses yang melibatkan berbagai sumber yakni masyarakat yang dituju, dana serta kemampuan Bank Syariah Mandiri untuk mencapai tujuan yang sudah ditetapkan sehingga berdampak pada hasil yang dapat bermanfaat untuk orang banyak.

Terdapat dua program utama penyaluran dana CSR BSM; pertama adalah Program Dasar, yakni Cabang Bank Syariah Mandiri yang menunjukkan kinerja positif dapat mengalokasikan dana kegiatan CSRnya sebesar Rp. 20 juta dan kedua adalah Program Khusus dimana Cabang Bank Syariah Mandiri yang menunjukkan kinerja positif diberi dana pengelolaan CSR tahunan dan triwulanan berdasarkan kinerja. Program khusus tahunan diberikan pada cabang yang memiliki kinerja baik selama satu tahun. Cabang yang memiliki kinerja positif selama

\footnotetext{
${ }^{29}$ Dadang Ruhiyat, wawancara.

${ }^{30}$ Ma'ruf Amin, Era Baru Ekonomi Islam Indonesia: Dari Fikih ke Praktek Ekonomi Islam, (Jakarta: Elsas, 2011), h. 43.

${ }^{31}$ Jusri, , op. cit
} 
setahun akan mendapat alokasi pengelolaan dana CSR mulai dari Rp. 200 juta s/d Rp. 650 juta yang pengelolaannya dapat dialokasikan untuk infrastruktur masjid, untuk program sosial lainnya serta untuk biaya oprasional program CSR yang dilaksanakan. Bank Syariah Mandiri Cabang Kendari mendapatkan dana Pengelolaan CSR untuk tahun 2017 sebanyak Rp. 200 juta yang akan disalurkan pada beberapa tahapan berdasarkan capaian kerja yang dilakukan masyarakat penerima program CSR tersebut. ${ }^{32}$

Dadang Ruhiyat selaku Branch Manger di BSM Cabang Kendari menjelaskan bahwa ditahun 2017, tema Program CSR BSM adalah BSM Mengalirkan Berkah yang penyalurannya difokuskan pada kegiatan berbasis masjid. Kegiatan tersebut memiliki dasar pemikiran bahwa dimana ada BSM disitu Masjid terawat, karena jika masjidnya terawat jamaah akan senang untuk shalat berjamaah di Masjid. Dengan demikian, kehadiran BSM Cabang Kendari dapat dirasakan manfaatnya oleh masyarakat. ${ }^{33}$ Terdapat dua masjid yang mendapatkan dana program BSM Mengalirkan Berkah yaitu Masjid Al-Mu'Minin sebesar Rp. 200 Juta, terlihat pada proposal program BSM mengalirkan berkah khusus sebagai berikut:

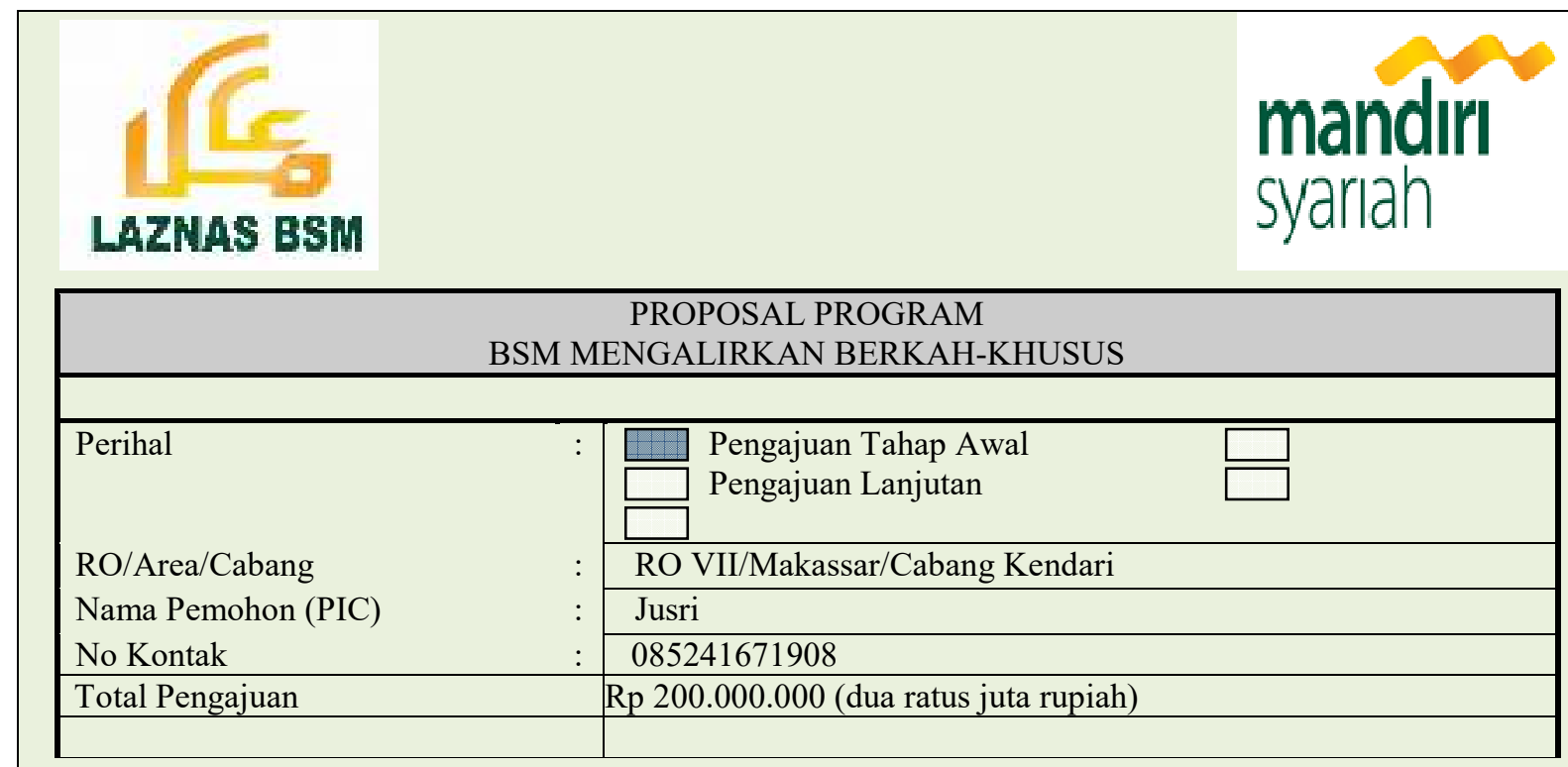

\begin{tabular}{|c|c|}
\hline Lampiran Berkas Utama & \\
\hline \begin{tabular}{|l|} 
Proposal \\
\end{tabular} & $\square$ Surat penunjukan PIC RO/Area/Branch \\
\hline \begin{tabular}{|l|} 
Susunan Pengurus Masjid \\
\end{tabular} & $\square$ Copy KTP Ketua Pengurus Masjid \\
\hline DDokumentasi Masjid & $\square$ \\
\hline Hasil Assesment & $\square$ \\
\hline
\end{tabular}

Assalaamu'alaikum Wr. Wb.

Dengan ini kami sampaikan permohonan pencairan dana program BSM Mengalirkan Berkah, sebagai berikut:

\section{A. PERMOHONAN}

Berdasarkan surat CSG No 19/223-3/CSG dan DSG No 19/0287-3/DSG yang menyatakan Branch Kendari berhak mendapatkan dana program BSM Mengalirkan Berkah kategori Khusus Tahunan, maka dengan ini kami mengajukan permohonan pencairan dana program tersebut dengan rincian sebagai berikut:

${ }^{32}$ Dadang Ruhiyat,wawancara, 31 Agustus 2017

${ }^{33}$ Dadang Ruhiyat, wawancara. 


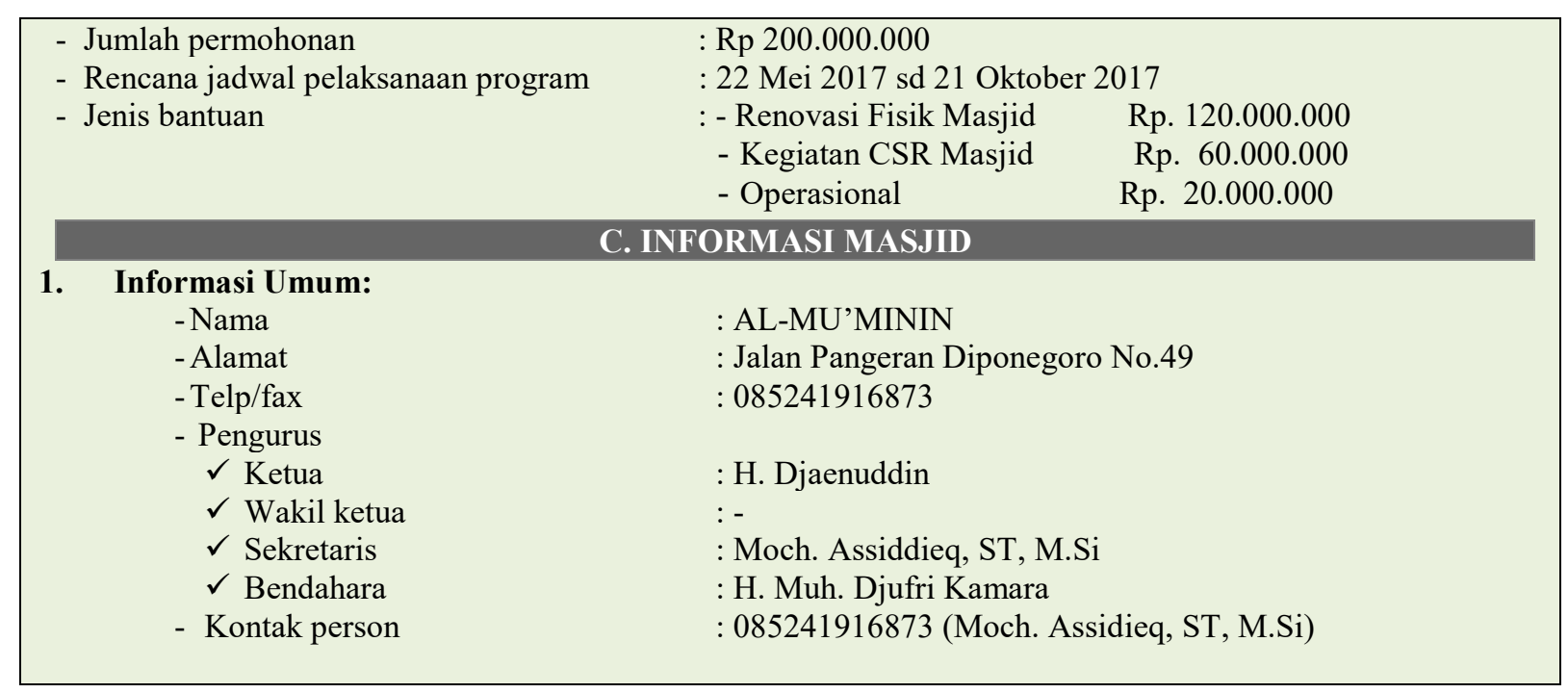

Berbeda dengan Masjid Al-Mu'Minin, Masjid Al-Arif mendapatkan penyaluran dana sebesar Rp. 12 Juta, hal tersebut berdasarkan laporan kegiatan program BSM mengalirkan berkan sebagai berikut:

\begin{tabular}{|c|c|c|c|c|c|c|}
\hline \multicolumn{7}{|c|}{ Contoh Format Laporan Kegiatan } \\
\hline \multicolumn{7}{|c|}{ PROGRAM BSM MENGALIR BERKAH } \\
\hline Per & riode : & Tahun 2017 & & & & \\
\hline \multicolumn{7}{|c|}{ Kriteria Basic } \\
\hline \multicolumn{7}{|c|}{ Nama Masjid : Al Arif } \\
\hline No & & Keterangan & $\begin{array}{c}\text { PJ } \\
\text { Anggaran } \\
\text { Kegiatan }\end{array}$ & $\begin{array}{l}\text { Deskripsi Hasil } \\
\text { Kegiatan }\end{array}$ & Permasalahan & Usulan Perbaikan \\
\hline \multirow[t]{3}{*}{ A1 } & \multicolumn{2}{|c|}{ PERSIAPAN PROGRAM } & & & & \\
\hline & A1-1 & Sosialisasi Program & 100,000 & Pertemuan dgn DKM & Kekurangan Dana & Penambahan T4 Wud \\
\hline & & Sub Total $=$ & 100,000 & & & \\
\hline \multirow[t]{15}{*}{$\mathbf{A 2}$} & \multicolumn{2}{|c|}{ BANTUAN LANGSUNG MASJID } & & & & \\
\hline & A2-1 & Pengadaan Perlengkapan pemeliharaan masjid & & & & \\
\hline & & Perlengkapan Sholat (mukena, sarung) & & & & \\
\hline & & Perlengkapan kebersihan (sapu,keset,pel) & & & & \\
\hline & & Perlengkapan pendukung lain (lemari gantung,sandal, keran) & & & & \\
\hline & & & & & & \\
\hline & & Sub Total $=$ & & & & \\
\hline & A2-2 & Renovasi minor & & & & \\
\hline & & Renovasi pembuatan tempat wudhu & $9,981,500$ & Pembuatan Tempat & Kekurangan T4 wudhu & Pembuatan Tempat \\
\hline & & & & wudhu baru & Wanita & wudhu baru \\
\hline & & Pekerja & & & & \\
\hline & & & & & & \\
\hline & & & & & & \\
\hline & & & & & & \\
\hline & & Sub Total $=$ & $9,981,500$ & & & \\
\hline \multirow[t]{3}{*}{ A3 } & \multicolumn{2}{|c|}{\begin{tabular}{|l|} 
PENDAMPINGAN PROGRAM \\
\end{tabular}} & & & & \\
\hline & & Insentif marbot & $1,818,500$ & & Tidak ada Insentif & Pemberian Insentif \\
\hline & & Sub Total $=$ & $1,818,500$ & & & \\
\hline \multirow[t]{5}{*}{ A4 } & BIAYA & PERASIONAL PROGRAM & & & & \\
\hline & & Publikasi Program & 100,000 & & & \\
\hline & & ATK dan Perlengkapan Pendukung Program & & & & \\
\hline & & Komunikasi & & & & \\
\hline & & Sub Total $=$ & 100,000 & & & \\
\hline & 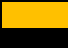 & TOTAL ANGGARAN BSM MENGALIRKAN BERKAH & 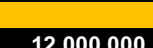 & & & \\
\hline
\end{tabular}

Selain program BSM mengalirkan berkah, di tahun 2017 Bank Syariah Mandiri Cabang Kendari juga melakukan program shalat subuh berjamaah di masjid-masjid yang berada di lingkungan ataupun wilayah kerja Bank Syariah Mandiri Cabang Kendari. ${ }^{34}$ Terdapat tiga masjid yang dikunjungi untuk program shalat subuh berjamaah, yaitu Masjid An-Nur, Masjid

\footnotetext{
${ }^{34}$ Jusri, wawancara tanggal 19 September 2017
} 
Wahdah serta Masjid Ahfadu Shohabah yang amsing-masing menerima dana sebesar Rp. 1 Juta rupiah.

Penggunaan besaran dana CSR BSM pada setiap kegiatannya dapat dibedakan berdasarkan penggunaan dana yang diperuntukkan pada persiapan program $2 \%$, bantuan langsung masjid $60 \%$, bantuan lain $30 \%$, pendampingan program $6 \%$, serta monitoring dan evaluasi $2 \%$, meskipun secara rinci program yang dilakukan setiap kegiatan bisa saja berbeda berdasarkan kebutuhan sebagaimana dalam tabel berikut. ${ }^{35}$

Tabel 1; Besaran Pemanfaatan Dana Corporate Sosial Responsibiliti Bank Syariah Mandiri Cabang Kendari

\begin{tabular}{|c|l|c|}
\hline No. & \multicolumn{1}{|c|}{ Kegiatan } & Besaran Dana (\%) \\
\hline 1. & Persiapan Program & 2 \\
\hline 2. & Bantuan Langsung Masjid & 60 \\
\hline 3. & Bantuan Lain & 30 \\
\hline 4. & Pendampingan Program & 6 \\
\hline 5. & Monitoring dan evaluasi & 2 \\
\hline
\end{tabular}

Sumber: Jusri, hasil wawancara 13 September 2017

Rincian program kegiatan berdasarkan anggaran program BSM mengalirkan berkah kriteria khusus dan kreteria basic Bank Syariah Mandiri Cabang Kendari tahun 2017 adalah sebagai berikut: ${ }^{36}$

1. Persiapan program berupa sosialisasi program, pertemuan dengan pihak masjid, pelatihan manajemen masjid serta pelatihan kader masjid. Ditahun 2017 sampai dengan bulan Oktober, baru dua masjid yang terlibat dan mendapatkan program BSM mengalirkan Berkah, yatu Masjid Al-Mu’Minin sebesar Rp. 200 Juta dan Masjid AlArif sebesar Rp. 12 Juta.

2. Bantuan langsung masjid, merupakan program pelaksanaan CSR BSM yang penyaluran dananya diperuntukkan bagi pembangunan/perbaikan infrastruktur masjid. Opsi penyaluran bantuan tersebut berupa:

a) Program renovasi inti bangunan masjid (atap, tiang, lantai, dinding), renovasi kubah, renovasi/pembuatan kanopi, renovasi tempat wudhu.

b) Program perlengkapan fasilitas bangunan inti; pengadaan mimbar, pengadaan jam digital, pengadaan karpet seluruh, pengadaan kipas angin.

c) Program pengembangan Lainnya; pembangunan TPA, fasilitas TPA (Meja, kursi, buku, Al-Qur'an, dll), bantuan pembuatan aula, perpustakaan (bangunan, buku, komputer), perlengkapan penyelenggaraan jenazah (tandu), pengadaan arena bermain (playground) sebagai infrastruktur TPA

3. Bantuan lain, merupakan program pelaksanaan CS RBSM yang penyaluran dananya diperuntukkan bagi selain pembangunan/perbaikan infrastruktur masjid. Opsi penyaluran bantuan tersebut berupa:

a) Program renovasi fisik non masjid yang dapat disalurkan pada program bedah rumah jamaah, program renovasi panti asuhan serta program sarana air bersih dan sanitasi.

b) Program kemanusiaan/darurat bencana yang berupa bantunan kepada korban bencana.

c) Program bidang kesehatan yang dapat disalurkan pada program sunatan massal, program operasi katarak serta program biaya pengobatan yang tidak ditanggung BPJS.

\footnotetext{
${ }^{35}$ Jusri, wawancara tanggal 13 September 2017

${ }^{36}$ Laporan Anggaran Program BSM Mengalirkan Berkah Kriteria Khusus dan kriteria Basic Bank Syariah Mandiri Cabang Kendari Tahun 2017
} 
d) Program bidang pendidikan yang dapat disalurkan pada program pengadaan sarana dan prasarana sekolah/TPA serta program beasiswa.

e) Program bidang dakwah yang dapat disalurkan pada program pesantren kilat, program peringatan hari besar Islam serta program rekrutment imam masjid.

4. Pendampingan program merupakan alokasi program bagi insentif marbot.

5. Monitoring dan evaluasi merupakan kegiatan oprasional program berupa transfortasi dan konsumsi monev, audit program serta pelaporan.

Selain mendapatkan dana untuk dialokasikan ke Masjid, Bank syariah Mandiri juga mendapatkan dana tambahan CSR sebanyak Rp. 100 juta yang akan dialokasikan untuk program beasiswa kepada 50 orang mahasiswa yang masing-masing mendapatkan beasiswa sebanyak Rp. 2 juta. Mahasiswa yang akan mendapatkan beasiswa dari pengelolaan dana CSR BSM Cabang Kendari adalah mahasiswa yang berasal dari Universitas Muhammadiyah Kendari. ${ }^{37}$

Tabel 2; Implementasi Program Corporate Social Responsibility Bank Syariah Mandiri Cabang Kendari sampai dengan Bulan Oktober

\begin{tabular}{|c|c|c|c|}
\hline No. & Nama Kegiatan & Lokasi Kegiatan & Jumlah \\
\hline \multirow[t]{2}{*}{1.} & \multirow{2}{*}{$\begin{array}{l}\text { Pembangunan/Renovasi Infrasturuktur } \\
\text { Masjid }\end{array}$} & 1. Masjid Al-Mu'Minin & Rp. 200 juta \\
\hline & & 2. Al-Arif & Rp. 12 juta \\
\hline \multirow[t]{3}{*}{2.} & \multirow{3}{*}{$\begin{array}{l}\text { Sumbangan untuk masjid pada program } \\
\text { subuh berjamaah }\end{array}$} & 1. Masjid An-Nur & Rp. 1 juta \\
\hline & & 2. Masjid Wahdah & Rp. 1 juta \\
\hline & & 3. Masjid Ahfadu Shohabah & Rp. 1 juta \\
\hline 3. & $\begin{array}{l}\text { Pengadaan air bersih yakni pengadaan alat } \\
\text { penjernih air di setiap sumur masyarakat }\end{array}$ & $\begin{array}{l}\text { Masyarakat sekitar masjid Al- } \\
\text { Mu'minin }\end{array}$ & - \\
\hline 4. & $\begin{array}{l}\text { Program beasiswa yang dialokasikan } \\
\text { kepada } 50 \text { mahasiswa }\end{array}$ & $\begin{array}{l}\text { Mahasiswa Universitas } \\
\text { Muhammadiyah Kendari }\end{array}$ & Rp. \\
\hline
\end{tabular}

Sumber: Jusri, hasil wawancara 05 Oktober 2017

\section{F. Pengawasan Program Corporate Social Responsibility di Bank Syariah Mandiri Cabang Kendari}

Pelaksanaan program corporate social responsibility Bank Syariah Mandiri cabang Kendari akan berjalan baik apabila pelaksanaan program tersebut adalah sebagai berikut:

1. Memperoleh dukungan dari pihak-pihak yang terlibat yakni dari pihak internal Bank Syariah Mandiri serta pihak eksternal masyarakat sebagai penerima alokasi program dana corporate social responsibility Bank Syariah Mandiri Cabang Kendari.

Dukungan internal yang diperoleh yakni dengan adanya dana program corporate social responsibility yang dikelola Bank Syariah Mandiri Cabang Kendari sebesar Rp. 200 juta melalui penunjukkan langsung dari dari Bank Syariah Mandiri Pusat berdasarkan produktifitas tahun 2016.

Dukungan yang diperoleh dari pihak eksternal Bank Syariah Mandiri Cabang Kendari merupakan dukungan dari masyarakat yang memperoleh penyaluran dana program corporate social responsibility maupun dana program sosial lainnya bahwa mereka mengikuti prosedur penyaluran dana-dana tersebut.

2. Adanya pola hubungan antara Bank Syariah Mandiri Cabang Kendari dengan pihakpihak yang mendapatkan penyaluran dana program corporate social responsibility maupun dana program sosial lainnya yang dapat dibuktikan dengan adanya kerjasama yang baik antara kedua belah pihak, dimana bank Syariah Mandiri Cabang Kendari menginformasikan secara jelas bagaimana mekanisme serta pemanfaatan dana

\footnotetext{
${ }^{37}$ Jusri, wawancara tanggal 05 Oktober 2017
} 
corporate sosial responsibility. Masyarakat penerima manfaat program corporate social responsibility juga melaporkan secara berkala mengenai capaian pelaksanaan program yang diamanahkan kepadanya. Dengan adanya pola kerjasama tersebut dapat meningkatkan kualitas koordinasi pelaksanaan program corporate social responsibility yang berkelanjutan.

3. Pengelolaan program yang baik; untuk mendapatkan hasil yang diingikan sesuai harapan, Bank Syariah Mandiri cabang Kendari menunjuk salah satu stafnya sebagai pengelola penyaluran dana program corporate social responsibility dan program sosial lainnya sehingga dapat dilaksanakan dengan baik dan teratur. Dalam pelaksanaannya Bank Syariah Mandiri menunjuk stafnya, Jusri, Pawning Officer sebagai pengelola dana corporate social responsibility dan program sosial lainnya.

Mekanisme pola pengawasan terhadap program corporate social responsibility dan program sosial lainnya di lembaga perbankan syariah bisa melalui lembaga dewan pengawas syariah atau diserahkan pada kebijakan bank tersebut melalui pelaporan ${ }^{38}$ yang dibuat oleh staf yang ditugaskan untuk mengelola program corporate social responsibility dan program sosial lainnya. Laporan pertanggung jawaban penyaluran dana program sosial Bank Syariah Cabang Kendari yang bersumber dari dana kebajikan, dana zakat ataupun bersumber dari laba hasil kinerja positif Bank Syariah Mandiri Cabang Kendari ditugaskan kepada stafnya, Jusri yang dalam jabatan struktural sebagai Pawning Officer Bank Syariah Mandiri Cabang Kendari.

Pengawasan yang dilakukan Bank Syariah Mandiri Cabang Kendari yakni melalui pelaporan secara berkala yang dibuat oleh petugas yang ditunjuk untuk merealisasikan serta mengalokasikan dana sosial Bank syaraiah Mandiri cabang Kendari. Laporan kegiatan secara berkala tersebut berdasarkan capaian dari setiap penyaluran dana corporate social responsibility dan program sosial lainnya. ${ }^{39}$

\section{G. Penutup}

Program CSR yang dilakukan Bank Syariah Mandiri Cabang Kendari bertujuan mendukung kesejahteraan masyarakat serta meningkatkan kualitas lingkungan, membuat perubahan positif di tengah masyarakat, meningkatkan nilai brand Bank Syariah Mandiri dan membangun reputasi yang baik. Dana sosial Bank Syariah Mandiri cabang Kendari disalurkan pada kegiatan Program Mitra Umat, Program Didik Umat, Program Sosial dan Budaya serta Program Pelestarian Lingkungan. Untuk Program corporate social responsibility tahun 2017 Bank Syariah Mandiri memiliki tema BSM Mengalirkan Berkah.

Implementasi dari program CSR sampai dengan bulan Oktober 2017 diantaranya adalah Bank Syariah Mandiri cabang Kendari menyalurkan dana sosialnya pada pembangunan/renovasi infrasturuktur masjid, sumbangan untuk masjid pada program subuh berjamaah di lingkungan wilayah kerja Bank Syariah Mandiri Cabang Kendari, pengadaan air bersih yakni pengadaan alat penjernih air disumur masyarakat serta pemberian beasiswa bagi 50 mahasiswa.

\section{Daftar Pustaka}

Muhammad dan Lukman Fauroni, Visi Al-Qur'an tentang Etika dan Bisnis. Jakarta: Salemba Diniyah, 2002.

Primahendra, Riza. Corporate Social Responsibility sebagai Investasi Sosial. Jakarta: Brief Note, Amerta Sosial Consulting \& Resourching, 2010.

\footnotetext{
${ }^{38}$ Mohammad Bagus Teguh Perwira, op. cit.

${ }^{39}$ Jusri, op. cit.
} 
Qutb, Sayyid. Tafsir Fi Zhilalil Qur'an di Bawah Naungan Al-Qur'an, Jilid 4. Jakarta: Gema Insani Press, 2001.

Rachman, Nurdizal M., Asep Ependi \& Emir Wicaksana. Panduan Lengkap Perencanaan CSR. Jakarta: Penebar Swadaya, 2011.

Sakti, Ali. Analisis Teoritis Ekonomi Islam. Jakarta: Paradigma AQSA Publishing, 2007.

Untung, Hendrik B. Corporate Social Responsibility. Jakarta: Sinar Grafika, 2008.

Wibisono, Yusuf. Membedah Konsep dan Aplikasi CSR, cet. II. Gersik: Fascho Publishing, 2007.

Yasir, Yusuf. “Aplikasi Corporate Social Responsibility pada bank Syariah: suatu Pendekatan Maslahah dan Maqasid Syariah”. Jurnal EKSIBISI, Vol 4, No 2 (Juni, 2010).

Handriyani, Arik Novia. "Pengaruh Corporate Social Responsibility Terhadap Nilai Perusahaan Dengan Profitabilitas Sebagai Variabel Moderating", https:/ejournal.stiesia.ac.id/jira/article/viewFile/124/123

Putra, Anggara Satria. "Pengaruh Corporate social responsibility Terhadap Profitabilitas Perusahaan (Studi Empiris pada Perusahaan Sektor Industri Barang Konsumsi yang Terdaftar di Bursa Efek Indonesia Tahun 2010-2013)", Jurnal Nominal, Volume IV, Nomor 2, 2015. https://journal.uny.ac.id/index.php/nominal/article/view/8002/6771

Wahyuddin, "Islamic Corporate Social Responsibility (ICSR); Kajian Teoritis", http://jurnal2.serambimekkah.ac.id/wp-content/uploads/2016/05/

Kepmen BUMN Nomor: Kep-236/MBU/2003 tentang Program Kemitraan Bina Lingkungan $(P K B L)$.

http://www.jtanzilco.com/blog/detail/360/slug/people-equity-pendekatan-baru-talentmanagement-untuk-mendongkrak-kinerja-organisasi.Diakses tanggal 30 Agustus 2017

Laporan Anggaran Program BSM Mengalirkan Berkah Kriteria Khusus dan kriteria Basic Bank Syariah Mandiri Cabang Kendari Tahun 2017 